\title{
FAKTOR-FAKTOR YANG MEMPENGARUHI ORIENTASI KARIR INDIVIDU (SUATU TINJAUAN TEORITIS)
}

\author{
Harunnurrasyid \\ rasid.harun@gmail.com \\ Rahmi Widyanti \\ rahmiwidyanti@yahoo.com
}

Universitas Islam Kalimantan MAB Banjarmasin

\begin{abstract}
Career management is an employee career management process that covers the stages of career planning activities, career development and counseling, and career decision making. Career management involves all parties including employees concerned with the unit where the employee works, and the organization as a whole. Therefore, career management covers a vast area of activity. In this paper the stages to be discussed are about the factors that affect the career orientation of individuals.

Career management covers a vast area of activity. The importance of career management for employees is to increase the potential and productivity for their advancement, while for the company is to plan their human resources in improving the company's business value and business competition.

Career planning and development is a career management function. companies that want their employees to work with good skills and knowledge should be able to plan and develop their employees' careers, while for employees with career planning and development, employees can know their career goals and direction.
\end{abstract}

Keywords: factors, career orientation and personalia

\section{PENDAHULUAN}

Perencanaan karir adalah perencanaan yang dilakukan baik oleh individu pegawai maupun oleh organisasi berkenaan dengan karir pegawai, terutama mengenai persiapan yang harus dipenuhi seorang pegawai untuk mencapai tujuan karir tertentu. Yang perlu digarisbawahi, perencanaan karir pegawai harus dilakukan oleh kedua belah pihak yaitu pegawai yang bersangkutan dan organisasi. Jika tidak, maka perencanaan karir 
pegawai tidak akan menghasilkan rencana yang baik dan realistis.

Pengembangan karir adalah proses mengidentifikasi potensi karir pegawai, dan materi serta menerapkan cara-cara yang tepat untuk mengembangkan potensi tersebut. Secara umum, proses pengembangan karir dimulai dengan mengevaluasi kinerja pegawai. Proses ini lazim disebut sebagai penilaian kinerja (performance appraisal). Dari hasil penelitian kinerja ini kita mendapatkan masukan yang menggambarkan profil kemampuan pegawai (baik potensinya maupun kinerja aktualnya). Dari masukan inilah kita mengidentifikasi berbagai metode untuk mengembangkan potensi yang bersangkutan.

Tujuan dari penulisan ini adalah mendalami tentang manajemen karir dan faktor-faktor apa saja yang mempengaruhi orientasi karir individu.

\section{TINJAUAN TEORITIS}

Menurut Handoko (2005), karir adalah semua pekerjaan yang ditangani atau dipegang selama kehidupan kerja seseorang. Dengan demikian karir menunjukkan perkembangan para pegawai secara individual dalam jenjang jabatan atau kepangkatan yang dapat dicapai selama masa kerja dalam suatu organisasi.

Simamora

(2006), berpendapat bahwa kata karir dapat dipandang dari beberapa perspektif yang berbeda, antaralain dari perspektif yang obyektif dan subyektif. Dipandang dari perspektif yang subyektif, karir merupakan urut-urutan posisi yang diduduki oleh seseorang selama hidupnya, sedangkan dari perspektif yang obyektif, karir merupakan perubahan-perubahan nilai, sikap, dan motivasi yang terjadi karena seseorang menjadi semakin tua. Kedua perspektif tersebut terfokus pada individu dan menganggap bahwa setiap individu memiliki 
beberapa tingkat pengendalian memilih, menilai, menugaskan, dan terhadap nasibnya sehingga mengembangkan para pegawainya individu tersebut dapat guna menyediakan suatu kumpulan memanipulasi peluang untuk orang-orang yang berbobot untuk memaksimalkan keberhasilan dan memenuhi kebutuhan-kebutuhan di kepuasan yang berasal dari karirnya. masa yang akan datang.

Berdasarkan pengertian tersebut, Lebih lanjut Simamora (2006), maka pengertian karir adalah urutan aktivitas-aktivitas yang berkaitan dengan pekerjaan dan perilakuperilaku, nilai-nilai, dan aspirasiaspirasi seseorang selama rentang hidupnya.

\section{Konsep Perencanaan Karir}

Menurut Simamora (2006), perencanaan karir (career planning) adalah suatu proses dimana individu dapat mengidentifikasi dan mengambil langkah-langkah untuk mencapai tujuan-tujuan karirnya. Perencanaan karir melibatkan pengidentifikasian tujuan-tujuan yang berkaitan dengan karir dan penyusunan rencana-rencana untuk mencapai tujuan tersebut. Manajemen karir (career management) adalah proses dimana organisasi 
2. Orientasi investigatif

Individu tipe ini akan terpikat dengan karir yang melibatkan aktivitasaktivitas kognitif (berpikir, berorganisasi, pemahaman) daripada yang afektif (perasaan, akting, dan emosional). Beberapa contoh : biolog, ahli kimia, dan dosen.

3. Orientasi sosial.

Individu tipe ini akan terpikat dengan karir yang melibatkan aktivitasaktivitas antarpribadi daripada fisik atau intelektual. Beberapa contoh : psikologi klinis, layanan asing dan kerja sosial.

4. Orientasi konvensional.

Individu tipe ini akan terpikat dengan karir yang melibatkan aktivitasaktivitas terstruktur dan teratur. Beberapa contoh : akuntan dan bankir.

5. Orientasi perusahaan.

Individu tipe ini akan terpikat dengan karir yang melibatkan aktivitas aktivitas verbal yang ditujukan untuk mempengaruhi orang lain. Beberapa contoh : manajer, pengacara dan tenaga humas.

6. Orientasi artistik.

Individu tipe ini akan terpikat dengan karir yang melibatkan aktivitasaktivitas ekspresi diri, kreasi artistik, ekspresi emosi, dan individualistik. Beberapa contoh : artis, eksekutif periklanan, dan musisi.

Pada dasarnya perencana-an karir terdiri atas dua elemen utama yaitu perencanaan karir individual (individual career planning) dan perencanaan karir organisasional (organizational career planning). Perencanaan karir individual dan organisasional tidaklah dapat dipisahkan dan disendirikan. Seorang individu yang rencana karir individualnya tidak dapat terpenuhi didalam organisasi, cepat atau lambat individu tersebut akan meninggalkan perusahaan. Oleh karena itu, organisasi perlu membantu karyawan dalam perencanaan karir sehingga 
keduanya dapat saling memenuhi kebutuhan. (Mondy, 1993).

\section{Konsep Manajemen Karir}

Menurut Dessler (2006) kegiatan personalia seperti penyaringan, pelatihan, dan penilaian berfungsi untuk dua peran dasar dalam organisasi, yaitu : (a) Peran pertama, peran tradisional adalah menstafkan organisasi mengisi posisi-posisinya dengan karyawan yang mempunyai minat, kemampuan dan keterampilan yang memenuhi syarat; (b) Peran kedua adalah memastikan bahwa minat jangka panjang dari karyawan dilindungi oleh organisasi dan bahwa karyawan didorong untuk bertumbuh dan merealisasikan potensinya secara penuh. Anggapan dasar yang melandasi peran ini adalah bahwa majikan memiliki suatu kewajiban untuk memanfaatkan kemampuankemampuan karyawan secara penuh dan memberikan kepada semua karyawan suatu kesempatan untuk bertumbuh dan merealisasikan potensinya secara penuh serta berhasil dalam mengembangkan karirnya.

\section{METODOLOGI}

Dalam penulisan ini metode yang digunakan untuk memenuhi penyusunan penulisan ini adalah: 1). Studi kepustakaan, 2). penelusuran website.

\section{PEMBAHASAN}

\section{Perencanaan karir}

Perencanaan karir merupakan kegiatan atau usaha untuk mengatakan perjalanan karir pegawai serta mengidentifikasi halhal yang dapat dilakukan untuk mencapai tujuan karir tertentu.

Sesuai pemaparan sebelumnya, perencanaan karir dilakukan baik oleh pegawai maupun oleh organisasi. Sehingga, terdapat dua macam perencanaan karir, yaitu : 
- Perencanaan karir (di tingkat) perencanaan karir ditingkat individu organisasi (Organization career pegawai. panning).

$$
\text { Pada dasarnya tujuan }
$$

○ Perencanaan karir individual perencanaan karir untuk seorang pegawai (Individual career palnning).

\section{Perencanaan Karir di Tingkat Organisasi}

Perencanaan karir di tingkat organisasi dilakukan dengan tujuan untuk mengadakan atau mengidentifikasi hal-hal berikut :

a. Profil kebutuhan pegawai

b. Deskripsi jabatan/pekerjaan

c. Peta jalur karir

d. Mekanisme penilaian kinerja pegawai

\section{Perencanaan Karir Individual} Pegawai

Bagi pegawai, perencanaan karir ditingkat organisasi tidak akan dianggap penting bila tidak ada sangkut pautnya dengan karir si pegawai tersebut. Oleh karenanya, perencanaan karir ditingkat organisasi dapat menjadi

Urusan karir adalah urusan pegawai. Karena itu perencanaan karir harus melibatkan pegawai. Pegawai harus diajak berbicara, berdialog, bertanya jawab mengenai prospek mereka sendiri.

Ini kelihatannya mudah.

Tetapi di negara timur seperti Indonesia, karir jarang didialogkan denga pegawai. Pegawai sering kali merasa malu 
dan risih jika diajak bicara tentang karir mereka sendiri.

Mereka takut dianggap terlalu memikirkan karir dan ambisius. Karena itu, karir sering kali tabu dibicarakan.

Meskipun demikian dialog tentang karir ini harus diusahakan terjadi antara organisasi (misalnya diwakili seorang pimpinan) dengan pegawai. Melalui dialog inilah diharapkan timbul saling pengertian antara pegawai dan organisasi tentang prospek masa depan si pegawai.

b. Bimbingan

Tidak semua pegawai memahami jalur karir dan prospek karirnya sendiri. Karena itu, organisasi harus membuka kesempatan untuk melakukan bimbingan karir terhadap pegawai. Melalui bimbingan inilah pegawai dituntun untuk memahami berbagai informasi tentang karir mereka. Misalnya, pegawai dibimbing untuk mengetahui tujuan karir yang dapat mereka raih (jangka pendek atau jangka panjang), persyaratan untuk mencapai tujuan karir tersebut, serta usahausaha apa yang harus dilakukan agar tujuan tersebut dapat dicapai secara efisien.

c. Keterlibatan individual

Dalam rangka hubungan kerja yang manusiawi (humanistic) pegawai tidak boleh dianggap sebagai sekrup dari sebuah mesin bisnis yang besar, yang boleh diperlakukan semena- mena termasuk dalam penentuan nasib karir mereka.

Setiap individu pegawai seharusnya dilibatkan dalam proses perencanaan karir. Mereka harus diberi kesempatan berbicara dan memberikan masukan dalam proses tersebut. Jika tidak maka perencanaan karir akan berjalan timpang karena hanya dilihat dari sisi kepentingan organisasi belaka. 
d. Umpan balik

Sebenarnya, proses pemberian umpan balik selalu terjadi jika ada dialog. Tetapi dalam hal ini ingin ditegaskan bahwa setiap pegawai mempunyai hak untuk mrngetahui setiap keputusan yang berkenaan dengan karir mereka. Jika dipromosikan, mereka berhak tahu mengapa mereka dipromosikan. Bila tidak terjadi perubahan karir dalam waktu yang cukup lama, mereka juga berhak tahu mengapa hal ini terjadi. Pegawai berhak bertanya. Organisasi berkewajiban menjawab pertanyaan tersebut.

e. Mekanisme perencanaan karir Yang maksud di sini adalah tata cara atau prosedur yang ditetapkan agar proses perencanaan karir dapat dilaksanakan sebaik- baiknya. Dalam mekanisme perencanaan karir ini harus diusahakan agar empat hal di atas (dialog, bimbingan, keterlibatan individual, dan umpan balik) dapat terwadahi. Di samping itu, mekanisme seyogyanya dilengkapi dengan aturan atau prosedur yang lebih rinci, formal, dan tertulis.

Selain lima syarat diatas, kita juga perlu memahami bahwa sebagai manusia, seorang pegawai juga melalui tahapan-tahapan dalam perjalanan karirnya. Empat Tahapan Karir yang biasa dilalui seorang pegawai yaitu :

- tahap coba-coba

- tahap kemapanan

○ tahap pertengahan

- tahap lanjut.

Kebutuhan pegawai dalam hubungannya dengan pengembangan karirnya tidak selalu sama disuatu waktu tertentu. Secara umum, dapat kita katakan bahwa semakin matang seseorang semakin berubah kebutuhan pegawai itu, kearah yang lebih mapan, dan menjauh dari ambisi- ambisi untuk berkompetisi. 
Dengan demikian, wajarlah bila perencanaan karir seseorang harus disesuaikan dengan tahapan kematangan pribadinya. Hanya dengan demikian perencanaan karir seseorang dapat mengakomodasi kebutuhan- kebutuhan si pegawai tersebut.

Ada beberapa tahap yang perlu kita lakukan dalam proses perencanaan karir pegawai. Tahap tersebut yaitu :

a. Analisis Kebutuhan Karir Individu

Analisis kebutuhan karir individu, dalam hubungannya dengan karir pegawai, adalah proses mengidentifikasi potensi (kekuatan) dan kelemahan yang dimiliki oleh seorang pegawai, agar dengan demikian karir pegawai yang bersangkutan dapat direncanakan dan dikembangkan sebaik- baiknya. Pada dasarnya, analisis kebutuhan karir individu ini dilakukan oleh dua pihak, yaitu atasan langsung dan pegawai itu sendiri.

b. Pemetaan Karir Individu

Jika analisis kebutuhan karir individu sudah dilakukan, maka hal ini diharapkan telah melahirkan profil (gambaran) yang lengkap tentang seorang pegawai. Jika hal ini telah tercapai, maka "peta kerier" pegawai tersebut seharusnya sudah dapat dibuat.

\section{Faktor Yang Mempengaruhi}

\section{Pengembangan Karir}

Kesuksesan

proses

pengembangan karir tidak hanya penting bagi organisasi secara keseluruhan. Dalam hal ini, beberapa hal atau faktor yang sering kali amat berpengaruh terhadap manajemen karir adalah :

- Hubungan pegawai dan organisasi

- Personalitas pegawai

- Faktor-faktor eksternal

- Politicking dalam organisasi

- System penghargaan 
- Jumlah pegawai

○ Ukuran organisasi

- Kultur organisasi

- Tipe manajemen

a. Hubungan Pegawai dan Organisasi

Dalam situasi ideal, pegawai organisasi berada dalam hubungan yang saling menguntungkan. Dalam keadaan ideal ini, baik pegawai maupun organisasi dapat mencapai produktifitas kerja yang tinggi.

Namun, kadangkala keadaan ideal ini gagal dicapai. Adakalanya pegawai sudah bekerja baik, tetapi organisasi tidak mengimbangi prestasi pegawai tersebut dengan penghargaan sewajarnya.

b. Personalia Pegawai

Kadangkala, manaje-men karir pegawai terganggu karena adanya pegawai yang mempunyai personalitas yang menyimpang (terlalu emosional, apatis, terlalu ambisius, curang, terlalu bebal, dan lain-lain).
Pegawai yang apatis, misalnya, akan sulit dibina karirnya sebab dirinya sendiri ternyata tidak perduli dengan karirnya sendiri. Begitu pula dengan pegawai yang cenderung terlalu ambisius dan curang.

c. Faktor Eksternal

Acapkali terjadi, semua aturan dalam manajemen karir di suatu organisasi menjadi kacau lantaran ada intervensi dari pihak luar. Seorang pegawai yang mempromosikan ke jabatan lebih tinggi, misalnya, mungkin akan terpaksa dibatalkan karena ada orang lain yang didrop dari luar organisasi.

d. Politicking Dalam Organisasi

Manajemen karir pegawai akan tersendat dan bahkan mati bila faktor lain seperti intrikintrik, kasak-kasak, hubungan antar teman, nepotisme, feodalisme, dan sebagainya, lebih dominan mempengaruhi karir 
seseorang dari pada prestasi kerjanya.

e. Sistem Penghargaan

Sistem manajemen (reward system) sangat mempengaruhi banyak hal, termasuk manajemen karir pegawai. Organisasi yang tidak mempunyai sistem penghargaan yang jelas (selain gaji dan insentif) akan cenderung memperlakukan pegawainya secara subyektif. Pegawai yang berprestasi baik dianggap sama dengan pegawai malas.

f. Jumlah Pegawai

Jumlah pegawai yang dimiliki sebuah organisasi sangat mempengaruhi manajemen karir yang ada. Jika jumlah pegawai sedikit, maka manajemen karir akan sederhana dan mudah dikelola. Jika jumlah pegawai banyak, maka manajemen karir menjadi rumit dan tidak mudah dikelola.

g. Ukuran Organisasi

Ukuran organisasi dalam konteks ini berhubungan dengan jumlah jabatan yang ada dalam organisasi tersebut, termasuk jumlah jenis pekerjaan, dan jumlah personel pegawai yang diperlukan untuk mengisi berbagai jabatan dan pekerjaan tersebut. biasanya, semakin besar organisasi, semakin kompleks urusan manajemen karir pegawai. Namun, kesempatan untuk promosi dan rotasi pegawai juga lebih banyak.

h. Kultur Organisasi

Seperti sebuah sistem masyarakat, organisasi pun mempunyai kultur dan kebiasaan-kebiasaan. Ada organisasi yang cenderung berkultur professional, obyektif, raasional, dan demokratis. Ada juga organisasi yang cenderung feodalistik, rasional, dan demokratis. Ada juga organisasi yang cenderung menghargai prestasi kerja (sistem merit). Ada pula organisasi yang lebih menghargai senioritas dari pada hal-hal lain. 
i. Tipe Manajemen

Secara teoritis-normatif, semua manajemen sama saja di dunia ini. Tetapi dalam impelemntasinya, manajemen di suatu organisasi mungkin amat berlainan dari manajemen di organisasi lain. Ada manajemen yang cemderung kaku, otoriter, tersentralisir, tertutup, tidak demokratis. Ada juga manajemen yang cenderung fleksibel, partisipatif, terbuka, dan demokratis.

Jika manajemen cenderung kaku dan tertutup, maka keterlibatan pegawai dalam hal pembinaan karirnya sendiri juga cenderung minimal. Sebaliknya, jika manajemen cenderung terbuka, partisipatif, dan demokratis, maka keterlibatan pegawai dalam pembinaan karir mereka juga cenderung besar.

Selain itu, pengembangan karir pegawai dapat dipengaruhi oleh minat, bakat dan kemampuan individu yang bersangkutan (Widyanti dkk, 2012). Apabila individu bekerja sesuai dengan minat dan bakat serta kemampuan yang dimiliki pengembangan karir karyawan dapat berjalan dengan baik.

\section{KESIMPULAN DAN SARAN \\ Kesimpulan}

1. Dengan pengenalan dan pembahasan tentang manajemen karir dapat ditarik suatu kesimpulan bahwa manajemen karir melibatkan semua pihak termasuk pegawai yang bersangkutan dengan unit tempat si pegawai bekerja, dan organisasi secara keseluruhan. Oleh karena itu manajemen karir mencakup area kegiatan yang sangat luas. Pentingnya manajemen karir bagi karyawan adalah untuk meningkatkan potensi dan produktifitas bagi kemajuan dirinya, sedangkan bagi perusahaan adalah untuk merencanakan SDM mereka 
dalam meningkatkan nilai bisnis perusahaan dan kompetisi bisnis.

2. Perencanaan dan pengembangan karir merupa-kan fungsi manajemen karir. perusahaan yang ingin karyawan mereka dapat bekerja dengan skill dan pengetahuan yang baik harus dapat merencanakan dan mengembangkan karir pegawainya, sedangkan bagi pegawai dengan adanya perencanaan dan pengembangan karir, pegawai dapat mengetahui tujuan dan arah karir mereka.

\section{Saran}

1. Dalam organisasi, terdapat berbagai masalah yang berhubungan dengan karir pegawai. Ada yang tidak terlampau serius sehingga dapat dipecahkan dalam tempo relatif cepat. Ada pula yang sangat serius sehingga mengganggu pekerjaan si pegawai sendiri maupun pekerjaan rekan sekerja lainnya. Dalam keadaan seperti ini, konseling karir sangat diperlukan, baik oleh pegawai maupun oleh organisasi. Bahkan organisasi yang cukup besar seringkali merasa perlu mempekerjakan seorang pakar (konselor) yang khusus menangani masalah-masalah karir ini.

\section{DAFTAR PUSTAKA}

Dessler, Gary. 2006. Manajemen Sumber Daya Manusia, Edisi Indonesia. Jakarta: Pnerbit Prenhallindo.

Handoko, Hani T. 2005. Manajemen Personalia dan Sumber Daya Manusia. Yogyakarta: BPFE

Hasibuan, Malayu SP. 2003. Manajemen Sumber Daya Manusia. Jakarta: Bumi Aksara

Mondy, W. R dan Robert M. Noe. 1993. Human Resouces Management. Allyn \& Bacon.

Simamora, Henry. 2006. Manajemen Sumber Daya Manusia. Yogyakarta: Penerbit STIE YKPN

Walker, J.W. 1990. Managing Human Resources in a Flat, Lean, and Flexible 
Organization: Trends for The 1990's". Human Resource Planning. Vol. 11: 125-132.

Widyanti, Rahmi dkk., 2012, The perception of Individual and Organizational Careers in increasing the Organizational Commitment, Journal of Economics, Business, and Accountancy, Ventura, Vol.15, No.2, August 2012, pages 231244. 